\title{
PENGARUH PERSEPSI MENGENAI SISTEM BAGI HASIL, PERSEPSI LABA, DAN PERSEPSI TINGKAT SUKU BUNGA TERHADAP KEPUTUSAN UMKM MENGAMBIL PEMBIAYAAN MUDHARABAH \\ (Studi pada: Koperasi Jasa Keuangan Syariah Baitul Maal WatTamwil Bina Ummat Sejahtera Cabang Utama (KJKS BMT BUS CU) Lasem)
}

\author{
Oleh: \\ Zayyinatul Khusna \\ Prodi Akuntansi Universitas Negeri Yogyakarta \\ zayyina16@gmail.com
}

\begin{abstract}
Abstrak : Pengaruh Persepsi Mengenai Sistem Bagi Hasil, Persepsi Laba, Dan Persepsi Tingkat Suku Bunga Terhadap Keputusan Umkm Mengambil Pembiayaan Mudharabah (Studi Pada: Koperasi Jasa Keuangan Syariah Baitul Maal Wattamwil Bina Ummat Sejahtera Cabang Utama (Kjks Bmt Bus Cu) Lasem). Penelitian ini merupakan penelitian asosiatif. Penelitian ini bertujuan untuk mengetahui: 1) Pengaruh Persepsi Mengenai Sistem Bagi Hasil terhadap Keputusan UMKM Mengambil Pembiayaan Mudharabah pada KJKS BMT BUS CU Lasem, 2) Pengaruh Persepsi Laba terhadap Keputusan UMKM Mengambil Pembiayaan Mudharabah pada KJKS BMT BUS CU Lasem, 3) Pengaruh Persepsi Tingkat Suku Bunga terhadap Keputusan UMKM Mengambil Pembiayaan Mudharabah pada KJKS BMT BUS CU Lasem, 4) Pengaruh Persepsi Mengenai Sistem Bagi Hasil, Persepsi Laba, dan Persepsi Tingkat Suku Bunga terhadap Keputusan UMKM Mengambil Pembiayaan Mudharabah pada KJKS BMT BUS CU Lasem. Hasil penelitian ini menunjukkan bahwa Persepsi Mengenai Sistem Bagi Hasil $\left(X_{I}\right)$ berpengaruh positif dan signifikan terhadap Keputusan UMKM Mengambil Pembiayaan Mudharabah (Y), yang ditunjukkan dengan nilai koefisien regresi $(r)$ sebesar 0,313, nilai thitung $>t_{\text {tabel }}$ pada taraf signifikansi 5\% yaitu sebesar 5,948>1,6525. Persepsi Laba $\left(X_{2}\right)$ berpengaruh positif dan signifikan terhadap Keputusan UMKM Mengambil Pembiayaan Mudharabah (Y), yang ditunjukkan dengan nilai koefisien regresi $(r)$ sebesar 0,224 , nilai $t_{\text {hitung }}>t_{\text {tabel }}$ pada taraf signifikansi 5\% yaitu sebesar 5,501>1,6525. Persepsi Tingkat Suku Bunga $\left(X_{3}\right)$ berpengaruh positif namun tidak signifikan terhadap Keputusan UMKM Mengambil Pembiayaan Mudharabah (Y), yang ditunjukkan dengan nilai koefisien regresi $(r)$ sebesar 0,205 nilai $t_{\text {hitung }}>t_{\text {tabel }}$ pada taraf signifikansi 5\% yaitu sebesar 3,019>1,6525. Persepsi Mengenai Sistem Bagi Hasil $\left(X_{1}\right)$, Persepsi Laba $\left(X_{2}\right)$, dan Persepsi Tingkat Suku Bunga $\left(X_{3}\right)$ secara simultan berpengaruh positif dan signifikan terhadap Keputusan UMKM Mengambil Pembiayaan Mudharabah (Y), yang ditunjukkan dengan koefisien determinasi $\left(R^{2}\right)$ sebesar 0,165 dan nilai $F_{\text {hitung }}>F_{\text {tabel }}$ pada taraf signifikansi 5\% yaitu sebesar 17,048>2,11.
\end{abstract}

Kata kunci: Persepsi Mengenai Sistem Bagi Hasil, Persepsi Laba, Persepsi Tingkat Suku Bunga, Keputusan UMKM Mengambil Pembiayaan Mudharabah

Abstract : The Effect Of Perception Of Loss And Profit Sharing System, Perception Of Earning And Perception Of Interest Rate For Smes Take The Decision Of Mudharabah Financing (Studies On: Islamic Financial Services Cooperatives Baitul Maal Wattamwil Bina Ummat Sejahtera In Main Unit (Kjks Bmt Bus Mu) Lasem). This research belongs to associative research. The purposes of the research are to know: 1) the effect of Perception of Loss and Profit Sharing Sistem to SME's Take The Decision of Mudharabah Financing on KJKS BMT BUS MU Lasem, 2) the effect of Perception of Earning to SME's Take The Decision of Mudharabah Financing on KJKS BMT BUS MU Lasem, 3) the effect of Perception of Interest Rate to SME's Take The Decision Of Mudharabah Financing on KJKS BMT BUS MU Lasem, 4) the effect of Perception of Loss and Profit Sharing System, Perception of Earning, and Perception of Interest Rate to SME's Take The Decision of Mudharabah Financing on KJKS BMT BUS MU Lasem. The result of this research indicates that significant positive effect on Perception of Loss and Profit Sharing System to SME's Take The Decision of Mudharabah Financing on KJKS BMT BUS MU Lasem, showed by regression coefficient value $(r) 0,313, t_{\text {count }}>t_{\text {table }}$ on significance level $5 \%$ is 5,948>1,6525. Perception of Earning indicates 
significant positive effect on SME's Take The Decision of Mudharabah Financing on KJKS BMT BUS MU Lasem, showed by regression coefficient value $(r) 0,224, t_{\text {count }}>t_{\text {table }}$ on significance level $5 \%$ is 5,501>1,6525. Perception of Interest Rate indicates insignificant positive effect on SME's Take The Decision of Mudharabah Financing on KJKS BMT BUS MU Lasem, showed by regression coefficient value (r) 0,205, $t_{\text {count }}>t_{\text {table }}$ on significance level 5\% is 3,019>1,6525. Perception of Loss and Profit Sharing System, Perception of Earning, and Perception of Interest Rate are simultaneously that indicates significant positive effect on SME's Take The Decision of Mudharabah Financing on KJKS BMT BUS MU Lasem, showed by determination coefficient value $\left(R^{2}\right) 0,165$ and $F_{\text {count }}>F_{\text {table }}$ on significance level $5 \%$ is $17,048>2,11$.

Key words: Perception of Loss and Profit Sharing System, Perception of Earning, Perception of Interest Rate, SME's Take The Decision of Mudharabah Financing.

\section{PENDAHULUAN}

Usaha Mikro, Kecil, dan Menengah (UMKM) merupakan salah satu sektor usaha yang menjadi tulang punggung perekonomian nasional. UMKM menunjukkan peran pentingnya dalam perekonomian Indonesia dengan memberikan kontribusi yang besar dalam pendapatan nasional. Selain itu, UMKM memiliki jumlah yang banyak dan mencakup setiap sektor ekonomi sehingga dapat memberikan potensi yang besar dalam penyerapan tenaga kerja.

Data UMKM yang tercatat pada Kementrian Koperasi dan Usaha Kecil dan Menengah Republik Indonesia pada tahun 2013, menunjukkan angka perkembangan UMKM tahun 2011-2012 sebesar 2,41\% dari 55.206.444 unit menjadi 56.534.592 unit. Bertambahnya jumlah UMKM tentunya diikuti dengan bertambahnya jumlah tenaga kerja yang diserap oleh UMKM. Data menunjukkan perkembangan tenaga kerja yang diserap oleh UMKM tahun 2011-2012 sebanyak 5,83\% dari
101.722.458 menjadi 107.657.509.

Sedangkan kontribusi terhadap PDB pada tahun 2011 sebesar 57,94 dari persentase total dan tahun 2012 sebesar 59,08 dari persentase total.

Pertumbuhan UMKM yang semakin meningkat inilah yang mebuat pemerintah memberikan dukungan-dukungan dengan dikeluarkannya kebijakan-kebijakan terkait UMKM. Namun kebijakan pemerintah belum mendapatkan dukungan penuh dari pihak-pihak lainnya, terutama pihak perbankan yang memberikan bantuan permodalan. Sehingga UMKM mencari alternatif lain untuk menambah permodalannya dengan cara mengajukan pembiayaan pada Lembaga Keuangan Syariah (LKS). Baitul Maal WatTamwil (BMT) merupakan salah satu LKS yang memberikan bantuan permodalan khusunya pada usaha mikro. Namun tidak menutup kemungkinan BMT memberikan pembiayaan pada usaha kecil serta menengah, mengingat banyak BMT yang berkembang dengan baik. 


\section{JURNAL NOMINAL / VOLUME V NOMOR 1 / TAHUN 2016}

Produk pembiayaan yang biasanya ditawarkan oleh BMT yaitu pembiayaan mudharabah, musyarakah, Baibitsamanajil, Jual Beli Salam, Istishna', Ijarah, Qordul Hasan dan lain sebagainya. Di KJKS BMT Bina Ummat Sejahtera sendiri terdapat beberapa produk pembiayaan yang tidak jauh berbeda dengan BMT pada umumnya. Beberapa produk pembiayaan yang ditawarkan oleh KJKS BMT Bina Ummat Sejahtera di antaranya pembiayaan mudharabah, Baibitsamanajil, Ijarah, dan Qordul Hasan. Pembiayaan mudharabah merupakan pembiayaan modal kerja yang sebenarnya cocok untuk UMKM dalam menambahkan modal kerja. Namun saat ini pada KJKS BMT BUS, UMKM lebih memilih menggunakan akad murabahah (jual beli) untuk membantu mengembangkan usahanya. Sedangkan teori ekonomi Islam menyebutkan akad kerjasama dalam usaha yaitu akad mudharabah dan musyarakah.

Akad mudharabah merupakan akad kerja sama usaha antara pemilik dana dan pengelola dana dengan membagi keuntungan sesuai dengan bagian yang telah disepakati. PSAK 105 membagi kontrak mudharabah menjadi tiga jenis, yaitu mudharabah muqayyadah, mudharabah muthlaqah, dan mudharabah musytarakah. Mudharabah muqayyadah merupakan kerja sama mudharabah dengan kondisi pengelola diberi pembatasan oleh pemilik dana. Mudharabah muthlaqah merupakan kerja sama antara pemilik dana dan pengelola tanpa adanya pembatasan oleh pemilik dana. Mudharabah musytarakah merupakan bentuk kerja sama mudharabah dimana pengelola dana ikut menyertakan modal atau dananya (Rizal Yaya, dkk. 2009). Akad mudharabah yang biasanya berlaku pada lembaga keuangan syariah yaitu jenis akad mudharabah muthlaqah.

UMKM dalam memutuskan untuk mengambil pembiayaan tentunya mempunyai beberapa pertimbangan (Rio Sudirman, 2006), di antaranya yaitu sistem yang digunakan oleh lembaga keuangan, besarnya bagi hasil ataupun tingkat suku bunga yang berlaku, lokasi dan pelayanan yang diberikan, serta laba yang diperoleh dalam menjalankan usahanya. UMKM tentu akan mempertimbangkan hal yang sama sebelum memutuskan untuk mengambil pembiayaan mudharabah.

UMKM dalam mengambil keputusan untuk menambah modal dengan menggunakan pembiayaan mudharabah akan mempertimbangkan sistem yang digunakan. Pembiayaan mudharabah merupakan salah satu pembiayaan yang menggunakan prinsip loss and profit sharing yang biasa disebut dengan bagi hasil. Prinsip bagi hasil merupakan prinsip dimana keuntungan yang didapatkan dalam kerja sama usaha dibagi sesuai dengan kesepakatan dan kerugian yang terjadi (bukan kelalaian salah satu pihak) 


\section{JURNAL NOMINAL / VOLUME V NOMOR 1 / TAHUN 2016}

ditanggung bersama sehingga tidak ada pihak yang merasa dirugikan. Bagi hasil menghindari prinsip mendapatkan keuntungan secara sepihak dari kerja sama yang dijalankan. Prinsip inilah yang dirasa cocok digunakan oleh UMKM dalam penambahan modal untuk mengembangkan usahanya. Hal ini dikarenakan UMKM tidak akan dirugikan apabila melakukan pembiayaan mudharabah, sehingga UMKM memilih mengambil pembiayaan mudharabah.

Tingkat suku bunga yang ditetapkan oleh lembaga keuangan lainnya merupakan salah satu faktor yang menjadi pertimbangan UMKM sebelum mengambil pembiayaan mudharabah. Tingkat suku bunga oleh lembaga keuangan lainnya yang tinggi menyebabkan UMKM untuk memilih menggunakan pembiayaan mudharabah. Hal ini dikarenakan biaya yang harus ditanggung apabila UMKM mengambil kredit pada lembaga keuangan lainnya lebih tinggi dibandingkan dengan biaya yang ditanggung atas pengambilan pembiayaan mudharabah yang memperhitungkan biaya sesuai dengan laba yang didapatkan.

Laba yang diperoleh UMKM dalam menjalankan usaha tentunya berbeda-beda setiap periodenya. Perbedaan perolehan laba tiap periode inilah yang menjadi salah satu pertimbangan UMKM dalam memutuskan mengambil pembiayaan mudharabah. UMKM yang memutuskan mengambil pembiayaan mudharabah tentunya merasa tidak terlalu terbebani dengan biaya yang harus ditanggung setelah mengambil pembiayaan. Hal ini dikarenakan pembiayaan mudharabah yang menggunakan sistem bagi hasil memperhitungkan biaya atas pembiayaan mudharabah yang biasa disebut dengan nisbah bagi hasil sesuai dengan hasil ataupun laba atas usaha yang dijalankan. Dengan demikian UMKM akan merasa tidak keberatan apabila harus membayar nisbah bagi hasil karena besarnya nisbah bagi hasil sesuai dengan laba yang diperoleh UMKM.

Pembiayaan mudharabah dengan menggunakan sistem bagi hasil memang memberikan keuntungan bagi UMKM karena nisbah bagi hasil yang dibayarkan atas pengambilan pembiayaan didasarkan pada besarnya laba yang diperoleh. Namun, pembiayaan mudharabah juga memiliki kelemahan yaitu UMKM dituntut untuk melaporkan laba yang diperolehnya setiap periode dengan jujur. Hal ini sangat sulit untuk dipenuhi oleh UMKM karena UMKM merasa bahwa laba yang diperolehnya merupakan hasil kerja keras sendiri tanpa mendapatkan bantuan dari pihak lain. Selain itu, tingkat suku bunga yang ditawaran oleh lembaga keuangan lainnya terkadang lebih rendah dibandingkan dengan persentase bagi hasil apabila dihitung menggunakan ratarata laba setiap periode. Kelebihan dan kekurangan inilah yang membuat UMKM 


\section{JURNAL NOMINAL / VOLUME V NOMOR 1 / TAHUN 2016}

untuk lebih mempertimbangkan keputusan mengambil pembiayaan mudharabah.

Persepsi UMKM mengenai sistem bagi hasil masih beragam, karena pemahaman yang melekat pada UMKM mengenai sistem bagi hasil juga beragam. Saat ini sistem bagi hasil kurang dikenal dan dipahami oleh masyarakat termasuk juga di dalamnya UMKM. Terdapat beberapa UMKM khususnya pelaku usaha mikro yang mengambil pembiayaan mudharabah menganggap bahwa bagi hasil yang harus dibayarkan pada KJKS BMT Bina Ummat Sejahtera merupakan bunga. Hal ini menunjukan bahwa terdapat beberapa UMKM yang belum mengerti konsep bagi hasil dan belum dapat membedakan bagi hasil dengan bunga. UMKM yang masih belum paham mengenai sistem bagi hasil pada akad mudharabah membuat pelaksanaannya kurang maksimal dan belum sesuai dengan syariat Islam. Sedangkan UMKM yang paham mengenai sistem bagi hasil juga belum bisa untuk diajak melakukan akad mudharabah sesuai dengan syariat Islam. Hal ini dikarenakan UMKM enggan untuk melaporkan dengan jujur laba yang diperolehnya kepada KJKS BMT Bina Ummat Sejahtera.

Pelaporan laba secara periodik oleh UMKM kepada KJKS BMT Bina Ummat Sejahtera perlu dilakukan dengan adanya kerja sama usaha di antara kedua belah pihak dengan menggunakan akad mudharabah. Hal ini dikarenakan akad mudharabah mengunakan sistem bagi hasil, sehingga keuntungan yang diperoleh pada usaha dibagi di antara kedua belak pihak sesuai dengan kesepakatan yang telah disepakati pada akad. Namun persepsi UMKM mengenai laba masih beragam. UMKM akan berusaha untuk mendapatkan laba yang tinggi dalam usahanya dan tidak perlu membagi dengan KJKS BMT Bina Ummat Sejahtera sesuai dengan persentase yang seharusnya.

Berbeda dengan sistem bagi hasil yang membagi keuntungan sesuai dengan kesepakatan yang ditentukan, sistem bunga menggunakan tingkat suku bunga yang telah ditentukan oleh salah satu pihak yaitu pihak bank. Bunga merupakan harga yang harus dibayarkan nasabah kepada bank apabila nasabah memiliki pinjaman. Anifah (2009) mengungkapkan bahwa "besarnya tingkat suku bunga pada bank konvensional dapat berpengaruh terhadap bank syari'ah baik secara langsung maupun tidak langsung”,

Terdapat dua macam suku bunga, yaitu suku bunga simpanan dan suku bunga pinjaman. Apabila terjadi kenaikan suku bunga, maka suku bunga simpanan dan suku bunga pinjaman juga akan mengalami kenaikan. Dengan adanya kenaikan suku bunga simpanan, bank konvensional akan mengalami keuntungan karena masyarakat cenderung memilih bank konvensional dalam penyimpanan dana. Keuntungan yang 


\section{JURNAL NOMINAL / VOLUME V NOMOR 1 / TAHUN 2016}

didapatkan oleh bank syari'ah dengan adanya kenaikan tingkat suku bunga yaitu masyarakat akan memilih melakukan pinjaman di bank syari'ah. Hal ini dikarenakan tingkat suku bunga pinjaman yang ditawarkan pada bank konvensional cukup tinggi, sehingga masyarakat memilih melakukan pinjaman dengan menggunakan metode bagi hasil di bank syari'ah. Selain itu, persepsi masyarkat akan bunga juga dapat mempengaruhi keputusan masyarakat dalam melakukan pinjaman ataupun simpanan.

\section{METODE PENELITIAN}

\section{Jenis Penelitian}

Penelitian ini termasuk dalam penelitian asosiatif, yaitu penelitian yang bertujuan untuk mengetahui hubungan antara dua variabel atau lebih. Penelitian ini juga termasuk penelitian survai dengan unit analisis yang diteliti adalah UMKM yang mengambil pembiayaan mudharabah pada KJKS BMT BUS CU Lasem. (Sugiyono, 2010)

\section{Waktu dan Tempat Penelitian}

Penelitian ini dilakukan di situs KJKS BMT BUS CU Lasem pada bulan Januari Mei 2014.
Definisi Operasional variabel

Keputusan UMKM Mengambil

Pembiayaan Mudharabah

Keputusan UMKM mengambil pembiayaan mudharabah merupakan keputusan UMKM dalam mengambil pembiayaan mudharabah. Variabel ini diukur melalui 6 item pernyataan.

\section{Persepsi Mengenai Sistem Bagi Hasil}

Persepsi mengenai sistem bagi hasil merupakan penilaian atau pemberian tanggapan oleh UMKM mengenai sistem bagi hasil yang diterapkan pada KJKS BMT Bina Ummat Sejahtera. Variabel ini diukur melalui 7 item pernyataan.

a. Persepsi Laba

Persepsi laba merupakan penilaian atau pemberian tanggapan oleh UMKM terhadap laba yang telah diperoleh dalam menjalankan usahanya. Variabel ini diukur melalui 9 item pernyataan,

b. Persepsi Tingkat Suku Bunga

Persepsi tingkat suku bunga merupakan penilaian pemberian tanggapan oleh UMKM mengenai tingkat suku bunga pada lembaga keuangan lainnya. Variabel ini diukur melalui 3 item pernyataan.

\section{Populasi dan Sampel}

Populasi dalam penelitian ini adalah UMKM yang mengambil pembiayaan mudharabah pada KJKS BMT BUS CU Lasem yang berjumlah 623. Penelitian ini mengambil 243 UMKM untuk dijadikan sampel. 


\section{JURNAL NOMINAL / VOLUME V NOMOR 1 / TAHUN 2016}

\section{Prosedur}

Dalam penelitian ini, peneliti berusaha mengumpulkan data yang akurat dengan menggunakan kuesioner. Peneliti melakukan uji instrumen untuk mengetahui apakah kuesioner yang diberikan dapat dipahami oleh subjek penelitian atau tidak. Uji coba instrumen ini dilakukan pada 30 UMKM yang mengambil pembiayaan mudharabah pada KJKS BMT BUS CU Lasem di luar sampel untuk menguji validitas dan reliabilitas pada instrumen penelitian.

\section{Data, Instrumen, dan Teknik}

\section{Pengumpulan}

Metode pengumpulan data dalam penelitian ini adalah dengan menggunakan kuesioner. . Kuesioner merupakan teknik pengumpulan data yang dilakukan dengan cara memberi seperangkat pertanyaan maupun pernyataan tertulis kepada responden (Sugiyono, 2010).

Data yang digunakan dalam penelitian ini adalah data primer, yaitu data yang diperoleh dari sumber asli yang secara khusus dikumpulkan oleh peneliti. Kuesioner yang disebarkan berupa daftar pernyataan tertulis mengenai masalah yang berkaitan dengan objek yang diteliti. Instrumen penelitian adalah suatu alat yang digunakan untuk mengukur fenomena alam maupun sosial (variabel penelitian) yang diamati (Sugiyono, 2010). Instrumen yang digunakan adalah kuesioner yang item-item pernyataan diambil dan dimodifikasi dari penelitian-penelitian terdahulu.

Kuesioner ini berisi tentang variabel terikat (keputusan UMKM mengambil pembiayaan mudharabah) dan variabel bebas (persepsi mengenai sistem bagi hasil, persepsi laba, dan persepsi tingkat suku bunga) dengan menggunakan skala pengukuran Likert. Skala Likert yang digunakan adalah rentang nilai 1 (sangat tidak setuju) sampai dengan 4 (sangat setuju).

\section{Teknik Analisis Data}

Peneliti melakukan uji coba instrumen pada member Kaskus agar dapat melakukan uji validitas dan reliabilitas terhadap instrumen.

Sebelum melakukan teknik analisis data, peneliti melakukan uji normalitas, uji linearitas, uji multikolinieritas dan uji heteroskedastisitas sebagai uji prasyarat penelitian ini.

Teknik analisis data yang digunakan untuk menguji hipotesis yaitu uji regresi linier sederhana dan uji regresi linier berganda.

\section{HASIL PENELITIAN DAN PEMBA- HASAN}

\section{Deskripsi Data Penelitian}

Penelitian ini menggunakan sampel sebanyak 244. Data dari hasil penelitian ini terdiri dari tiga variabel independen yaitu Persepsi Mengenai Sistem Bagi Hasil, 


\section{JURNAL NOMINAL / VOLUME V NOMOR 1 / TAHUN 2016}

Persepsi Laba, dan Persepsi Tingkat Suku Bunga, dan variabel dependen Keputusan UMKM Mengambil Pembiayaan Mudharabah. Deskripsi data yang disajikan meliputi nilai tertinggi, nilai terendah, mean (M) dan standar deviasi (SD).

Tabel 1. Analisis Statistik Deskriptif

\begin{tabular}{|c|c|c|c|c|c|}
\hline Variabel & $\mathrm{N}$ & Min & $\begin{array}{l}\text { Ma } \\
\mathrm{x}\end{array}$ & Mean & $\begin{array}{l}\text { Std. } \\
\text { Deviation }\end{array}$ \\
\hline $\begin{array}{l}\text { Keputusan } \\
\text { UMKM } \\
\text { Mengambil } \\
\text { Pembiayaan } \\
\text { Mudharabah }\end{array}$ & 244 & 12 & 23 & 18,49 & 1,949 \\
\hline $\begin{array}{l}\text { Persepsi } \\
\text { Mengenai } \\
\text { Sistem Bagi } \\
\text { Hasil }\end{array}$ & 244 & 15 & 26 & 21,19 & 2,225 \\
\hline Persepsi Laba & 244 & 18 & 33 & 27,28 & 2,901 \\
\hline $\begin{array}{l}\text { Persepsi } \\
\text { Tingkat Suku } \\
\text { Bunga }\end{array}$ & 244 & 5 & 11 & 7,32 & 1,178 \\
\hline
\end{tabular}

a. Keputusan UMKM Mengambil Pembiayaan Mudharabah

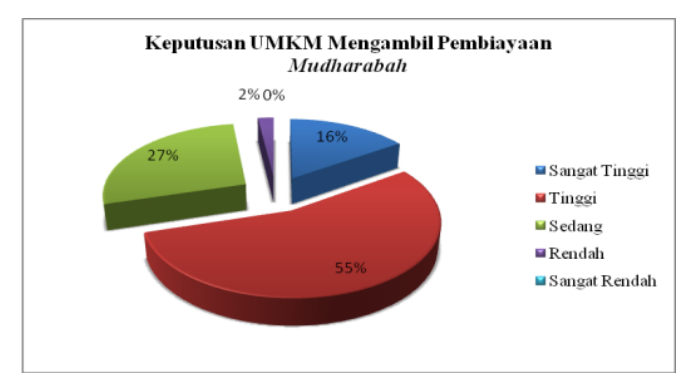

Gambar 1. Diagram Lingkaran Variabel Keputusan UMKM Mengambil Pembiayaan Mudharabah.

Berdasarkan diagram tersebut menunjukkan bahwa sebagian besar Keputusan UMKM Mengambil Pembiayaan
Mudharabah dalam kategori tinggi, yaitu ditunjukkan dari penilaian responden sebanyak 134 orang (55\%), kategori sangat tinggi sebanyak 38 orang (16\%), kategori sedang sebanyak 67 orang $(27 \%)$, dan kategori rendah sebanyak 5 orang (2\%).

b. Variabel Persepsi Mengenai Sistem Bagi Hasil

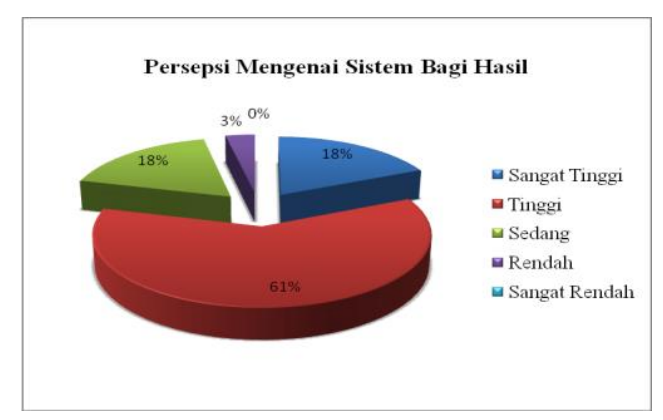

Gambar 2. Diagram Lingkaran Variabel Persepsi Mengenai Sistem Bagi Hasil

Berdasarkan diagram tersebut menunjukkan bahwa sebagian besar Persepsi Mengenai Sistem Bagi Hasil dalam kategori tinggi, yaitu ditunjukkan dari penilaian responden sebanyak 148 orang (61\%), kategori sangat tinggi sebanyak 45 orang (18\%), kategori sedang sebanyak 43 orang (18\%), dan kategori rendah sebanyak 8 orang $(3 \%)$. 
c. Variabel Persepsi Laba

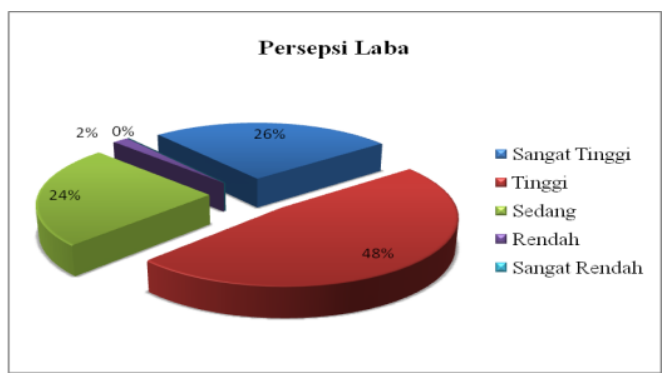

Gambar 3. Diagram Variabel Kualitas Informasi Member Kaskus

Berdasarkan diagram tersebut menunjukkan bahwa sebagian besar Persepsi Laba dalam kategori tinggi, yaitu ditunjukkan dari penilaian responden sebanyak 117 orang (48\%), kategori sangat tinggi sebanyak 63 orang (26\%), kategori sedang sebanyak 60 orang (24\%), dan kategori rendah sebanyak 4 orang $(2 \%)$.

d. Persepsi Tingkat Suku Bunga

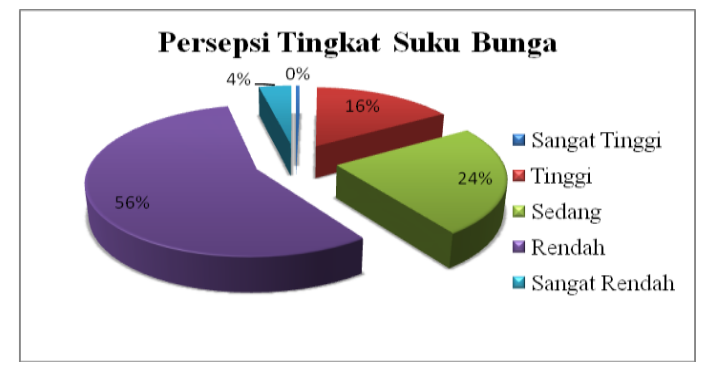

Gambar 4. Diagram Variabel Persepsi Risiko Member Kaskus

Berdasarkan diagram tersebut menunjukkan bahwa sebagian besar Persepsi Tingkat Suku Bunga dalam kategori rendah, yaitu ditunjukkan dari penilaian responden sebanyak 137 orang (56\%), kategori sangat tinggi sebanyak 1 orang (0\%), kategori tinggi sebanyak 39 orang (16\%), kategori sedang sebanyak 58 orang (24\%), dan kategori sangat rendah sebanyak 9 orang $(4 \%)$.

\section{Uji Hipotesis}

a. Uji Regresi Linier Sederhana

Regresi linear sederhana digunakan untuk mengetahui arah hubungan antara variabel independen terhadap variabel dependen secara parsial. Regresi linear sederhana ini digunakan untuk menguji hipotesis pertama, hipotesis kedua dan hipotesis ketiga. Uji hipotesis ini dilakukan dengan bantuan program SPSS for Windows. $\mathrm{H}_{1}$ : Persepsi Mengenai Sistem Bagi Hasil berpengaruh positif terhadap Keputusan UMKM Mengambil Pembiayaan Mudharabah pada BMT Bina Ummat Sejahtera Cabang Utama Lasem.

Tabel 2. Hasil Uji Hipotesis 1

\begin{tabular}{|c|c|c|c|}
\hline Variabel & $\begin{array}{c}\text { Koefisien } \\
\text { Regresi }\end{array}$ & $\begin{array}{c}\mathbf{t} \\
\text { hitung }\end{array}$ & Sig \\
\hline Persepsi & 0,313 & 5,948 & 0,000 \\
\hline Mengenai & & & \\
\hline Sistem & & & \\
\hline Bagi Hasil & & & \\
\hline Konstanta & $: 11,864$ & & \\
\hline $\mathbf{R}$ & $: 0,357$ & & \\
\hline R square & $: 0,128$ & & \\
\hline
\end{tabular}

Berdasarkan hasil perhitungan regresi linier sederhana yang ditunjukkan pada Tabel di atas, maka persamaan regresinya adalah sebagai berikut: 


\section{JURNAL NOMINAL / VOLUME V NOMOR 1 / TAHUN 2016}

$$
\mathrm{Y}=11,864+0,313 \mathrm{X}_{1}
$$

Persamaan tersebut menunjukkan bahwa konstanta sebesar 11,864; hal ini menunjukkan bahwa apabila variabel independen $\left(\mathrm{X}_{1}\right)$ dianggap nol, maka nilai variabel (Y) adalah sebesar 11,864 satuan. Koefisien regresi $\mathrm{X}_{1}$ sebesar 0,313 menunjukkan bahwa setiap kenaikan Persepsi Mengenai Sistem Bagi Hasil sebesar 1 satuan akan menaikkan Keputusan UMKM Mengambil Pembiayaan Mudharabah sebesar 0,313 satuan.

Nilai koefisien korelasi (R) bernilai positif sebesar 0,357 dan $R$ square $\left(R^{2}\right)$ yang diperoleh bernilai $0,128(12,8 \%)$. Hal ini berarti Persepsi Mengenai Sistem Bagi Hasil memiliki pengaruh positif dan mempengaruhi $12,8 \%$ perubahan pada Keputusan UMKM Mengambil Pembiayaan Mudharabah.

Pengujian signifikansi bertujuan untuk mengetahui signifikansi Persepsi Mengenai Sistem Bagi Hasil terhadap Keputusan UMKM Mengambil Pembiayaan Mudharabah. Berdasarkan hasil pengujian diperoleh nilai signifikansi lebih kecil dari $0,05(0,000<0,05)$, nilai $t$ hitung lebih besar dari $t$ tabel $(5,948>1,6525)$ maka hipotesis pertama dalam penelitian ini diterima.

$\mathrm{H}_{2}$ : Persepsi Laba berpengaruh positif terhadap Keputusan UMKM Mengambil Pembiayaan Mudharabah pada BMT Bina Ummat Sejahtera vabang Utama Lasem
Tabel 3. Hasil Uji Hipotesis 2

\begin{tabular}{lccc}
\hline Variabel & $\begin{array}{c}\text { Koefisien } \\
\text { Regresi }\end{array}$ & $\begin{array}{c}\text { t } \\
\text { hitung }\end{array}$ & Sig \\
\hline Kualitas & 0,224 & 5,501 & 0,000 \\
Informasi & & & \\
\hline Konstant & $: 12,382$ & & \\
a & & & \\
\hline R & $: 0,333$ & & \\
\hline R square & $: 0,111$ & & \\
\hline
\end{tabular}

Berdasarkan hasil analisis regresi tersebut dapat diketahui persamaan regresi satu prediktor sebagai berikut:

$$
\mathrm{Y}=12,382+0,224 \mathrm{X}_{2}
$$

Persamaan tersebut menunjukkan bahwa konstanta sebesar 12,382; hal ini menunjukkan bahwa apabila variabel independen $\left(\mathrm{X}_{2}\right)$ dianggap nol, maka nilai variabel (Y) adalah sebesar 12,382 satuan. Koefisien regresi $X_{2}$ sebesar 0,224 menunjukkan bahwa setiap kenaikan Persepsi Laba sebesar 1 satuan akan menaikkan Keputusan UMKM Mengambil Pembiayaan Mudharabah sebesar 0,224 satuan.

Nilai koefisien korelasi (R) bernilai positif sebesar 0,333 dan $R$ square $\left(R^{2}\right)$ yang diperoleh bernilai $0,111(11,1 \%)$. Hal ini berarti Persepsi Laba memiliki pengaruh positif dan mempengaruhi $11,1 \%$ perubahan pada Keputusan UMKM Mengambil Pembiayaan Mudharabah.

Pengujian signifikansi bertujuan untuk mengetahui signifikansi Persepsi Laba 


\section{JURNAL NOMINAL / VOLUME V NOMOR 1 / TAHUN 2016}

terhadap Keputusan UMKM Mengambil Pembiayaan Mudharabah. Berdasarkan hasil pengujian diperoleh nilai signifikansi lebih kecil dari $0,05(0,000<0,05)$, nilai $t$ hitung lebih besar dari t tabel $(5,501>1,6525)$ maka hipotesis pertama dalam penelitian ini

\section{diterima.}

$\mathrm{H}_{3}$ : Persepsi Tingkat Suku Bunga berpengaruh positif terhadap Keputusan UMKM Mengambil Pembiayaan Mudharabah pada BMT Bina Ummat Sejahtera vabang Utama Lasem

Tabel 4. Hasil Uji Hipotesis 3

\begin{tabular}{lccc}
\hline Variabel & $\begin{array}{c}\text { Koefisien } \\
\text { Regresi }\end{array}$ & hitung & \\
& & Sig \\
Persepsi & 0,205 & 1,942 & 0,053 \\
Risiko & & & \\
\hline Konstant & $: 16,991$ & & \\
a & & & \\
\hline r & $: 0,124$ & & \\
\hline R square & $: 0,015$ & & \\
\hline
\end{tabular}

Berdasarkan hasil analisis regresi tersebut dapat diketahui persamaan regresi satu prediktor sebagai berikut:

$$
\mathrm{Y}=16,991+0,205 \mathrm{X}_{3}
$$

Persamaan tersebut menunjukkan bahwa konstanta sebesar 16,991; hal ini menunjukkan bahwa apabila variabel independen $\left(\mathrm{X}_{3}\right)$ dianggap nol, maka nilai variabel (Y) adalah sebesar 16,991 satuan. Koefisien regresi $X_{3}$ sebesar 0,205 menunjukkan bahwa setiap kenaikan Persepsi Tingkat Suku Bunga sebesar 1

satuan akan menaikkan Keputusan UMKM Mengambil Pembiayaan Mudharabah sebesar 0,205 satuan.

Nilai koefisien korelasi (R) bernilai positif sebesar 0,124 dan $R$ square $\left(R^{2}\right)$ yang diperoleh bernilai $0,015(1,5 \%)$. Hal ini berarti Persepsi Tingkat Suku Bunga memiliki pengaruh positif dan mempengaruhi $1,5 \%$ perubahan pada Keputusan UMKM Mengambil Pembiayaan Mudharabah.

Pengujian signifikansi bertujuan untuk mengetahui signifikansi Persepsi Tingkat Suku Bunga terhadap Keputusan UMKM Mengambil Pembiayaan Mudharabah. Berdasarkan hasil pengujian diperoleh nilai signifikansi lebih besar dari 0,05 $(0,053>0,05)$ sehingga pengaruh Persepsi Tingkat Suku Bunga terhadap Keputusan UMKM Mengambil Pembiayaan Muddarabah tidak signifikan, namun nilai $\mathrm{t}$ hitung lebih besar dari $\mathrm{t}$ tabel $(5,501>1,6525)$ maka hipotesis pertama dalam penelitian ini diterima.

$\mathrm{H}_{4}$ : Persepsi Mengenasi Sistem Bagi Hasil, Persepsi Laba, dan Persepsi Tingkat Suku Bunga berpengaruh positif terhadap Keputusan UMKM Mengambil Pembiayaan Mudharabah pada BMT Bina Ummat Sejahtera Cabang Utama Lasem 
Tabel 5. Hasil Uji Hipotesis 4

\begin{tabular}{lc}
\hline \multicolumn{1}{c}{ Variabel } & $\begin{array}{c}\text { Koefisien } \\
\text { Regresi }\end{array}$ \\
\hline Konstanta & 9,194 \\
\hline Persepsi Mengenai & 0,215 \\
Sistem Bagi Hasil & \\
\hline Persepsi Laba & 0,146 \\
\hline Persepsi Tingkat Suku & 0,104 \\
Bunga & \\
\hline Adjusted R squared & $=0,157$ \\
\hline F Hitung & $=16,139$ \\
\hline F Tabel & $=2,11$ \\
\hline Signifikansi F & $=0,000$ \\
\hline
\end{tabular}

Berdasarkan tabel diatas, maka persamaan garis regresi dapat dinyatakan dalam persamaan sebagai berikut: $Y=9,194+0,215 X_{1}+0,146 X_{2}+0,104 X_{3}$

Persamaan tersebut menunjukkan bahwa nilai konstanta sebesar 9,194 dapat diartikan apabila variabel Persepsi Mengenai Sistem Bagi Hasil, Persepsi Laba, dan Persepsi Tingkat Suku Bunga tidak mengalami perubahan, maka Keputusan UMKM Mengambil Pembiayaan Mudharabah pada KJKS BMT BUS CU Lasem sebesar 9,194.

Nilai koefisien $\mathrm{X}_{1}$ sebesar 0,215 dapat diartikan apabila Persepsi Mengenai Sistem Bagi Hasil meningkat 1 poin maka Keputusan UMKM Mengambil Pembiayaan Mudharabah akan naik sebesar 0,215 satuan dengan asumsi $\mathrm{X}_{2}$ dan $\mathrm{X}_{3}$ tetap. Nilai koefisien $\mathrm{X}_{2}$ sebesar 0,146 yang berarti apabila Persepsi Laba meningkat 1 poin maka Keputusan UMKM Mengambil Pembiayaan Mudharabah akan naik sebesar 0,146 satuan dengan asmumsi $\mathrm{X}_{1}$ dan $\mathrm{X}_{3}$ tetap. Nilai koefisien $\mathrm{X}_{3}$ sebesar 0,104 yang berarti apabila Persepsi Tingkat Suku Bunga meningkat 1 poin maka Keputusan UMKM Mengambil Pembiayaan Mudharabah akan naik sebesar 0,104 satuan dengan asumsi $\mathrm{X}_{1}$ dan $\mathrm{X}_{2}$ tetap.

Nilai adjusted R square (R2) yang diperoleh bernilai $0,157(15,7 \%)$. Hal ini berarti Persepsi Mengenai Sistem Bagi Hasil, Persepsi Laba, dan Persepsi Tingkat Suku Bunga memiliki pengaruh positif dan mempengaruhi $15,7 \%$ perubahan pada Keputusan UMM Mengambil Pembiayaan Mudharabah.

Berdasarkan hasil uji pada tabel 5 diketahui bahwa nilai $\mathrm{F}$ hitung lebih besar daripada nilai $\mathrm{F}$ tabel $(16,139>2,11)$ dan nilai signifikansi lebih kecil dari 0,05 (0,000 $<$ 0,05) maka dapat disimpulkan bahwa Persepsi Mengenai Sistem Bagi Hasil, Persepsi Laba, dan Persepsi Tingkat Suku Bunga secara simultan memengaruhi terhadap Keputusan UMM Mengambil Pembiayaan Mudharabah pada KJKS BMT BUS CU Lasem, sehingga hipotesis yang keempat dalam penelitian ini diterima. 


\section{JURNAL NOMINAL / VOLUME V NOMOR 1 / TAHUN 2016}

\section{SIMPULAN DAN SARAN}

\section{Simpulan}

Berdasarkan hasil analisis dan pembahasan diatas, maka dapat ditarik kesimpulan sebagai berikut

a. Persepsi mengenai sistem bagi hasil berpengaruh positif terhadap keputusan UMKM mengambil pembiayaan mudharabah pada KJKS BMT Bina Ummat Sejahtera Cabang Utama Lasem. Hal ini dapat dibuktikan dengan nilai $t_{\text {hitung }}$ yang lebih besar dari $t_{\text {tabel }}$ $(5,948>1,6525)$ dan nilai signifikansi lebih kecil dari $0,05(0,000<0,05)$. Nilai koefisien regresi $\mathrm{X}_{1}$ sebesar 0,313 yang memiliki arah positif menunjukkan bahwa pengaruh yang dihasilkan adalah positif. Selain itu berdasarkan koefisien determinasi $\left(\mathrm{R}^{2}\right)$ yang bernilai $0,128 \quad(12,8 \%)$ menunjukkan persepsi mengenai sistem bagi hasil mempengaruhi 12,8\% perubahan keputusan UMKM mengambil pembiayaan mudharabah pada KJKS BMT Bina Ummat Sejahtera Cabang Utama Lasem.

b. Persepsi laba berpengaruh positif terhadap keputusan UMKM mengambil pembiayaan mudharabah pada KJKS BMT Bina Ummat Sejahtera Cabang Utama Lasem. Hal ini dapat dibuktikan dengan nilai $t_{\text {hitung }}$ yang lebih besar dari $t_{\text {tabel }}$ $(5,501>1,6525)$ dan nilai signifikansi lebih kecil dari 0,05 $(0,000<0,05)$. Nilai koefisien regresi $\mathrm{X}_{2}$ sebesar 0,224 yang memiliki arah positif menunjukkan bahwa pengaruh yang dihasilkan adalah positif. Selain itu berdasarkan koefisien determinasi $\left(\mathrm{R}^{2}\right)$ yang bernilai $0,111(11,1 \%)$ menunjukkan persepsi laba mempengaruhi $11,1 \%$ perubahan keputusan UMKM mengambil pembiayaan mudharabah pada KJKS BMT Bina Ummat Sejahtera Cabang Utama Lasem.

c. Persepsi tingkat suku bunga berpengaruh positif terhadap keputusan UMKM mengambil pembiayaan mudharabah pada KJKS BMT Bina Ummat Sejahtera Cabang Utama Lasem. Hal ini dapat dibuktikan dengan nilai thitung yang lebih besar dari $t_{\text {tabel }}(3,019>1,6525)$ dan nilai signifikansi lebih kecil dari $0,05(0,003<0,05)$. Nilai koefisien regresi $\mathrm{X}_{3}$ sebesar 0,205 yang memiliki arah positif menunjukkan bahwa pengaruh yang dihasilkan adalah positif. Selain itu berdasarkan koefisien determinasi $\left(\mathrm{R}^{2}\right)$ yang bernilai 0,036 (3,6\%) menunjukkan persepsi tingkat suku bunga mempengaruhi $3,6 \%$ perubahan keputusan UMKM mengambil pembiayaan mudharabah pada KJKS 


\section{JURNAL NOMINAL / VOLUME V NOMOR 1 / TAHUN 2016}

BMT Bina Ummat Sejahtera Cabang Utama Lasem.

d. Persepsi mengenai sistem bagi hasil, persepsi laba, dan persepsi tingkat suku bunga berpengaruh positif terhadap keputusan UMKM mengambil pembiayaan mudharabah pada KJKS BMT Bina Ummat Sejahtera Cabang Utama Lasem. Hal ini dapat dibuktikan dengan nilai $F_{\text {hitung }}$ yang lebih besar dari $\mathrm{F}_{\text {tabel }}$ $(17,048>2,11)$ dan nilai signifikansi lebih kecil dari $0,05(0,000<0,05)$. Koefisien regresi $\mathrm{X}_{1}, \mathrm{X}_{2}$, dan $\mathrm{X}_{3}$ masing-masing sebesar 0,224; 0,128 ; dan 0,141 yang semuanya memiliki arah positif menunjukkan bahwa hubungan ketiga variabel independen dengan variabel dependen memiliki arah positif. Selain itu berdasarkan koefisien determinasi $\left(\mathrm{R}^{2}\right)$ yang bernilai $0,165(16,5 \%)$ menunjukkan persepsi mengenai sistem bagi hasil, persepsi laba dan persepsi tingkat suku bunga mempengaruhi 16,5\% perubahan keputusan UMKM mengambil pembiayaan mudharabah pada KJKS BMT Bina Ummat Sejahtera Cabang Utama Lasem.

\section{Saran}

Berdasarkan hasil penelitian dan kesimpulan di atas, maka disarankan:

a. UMKM yang akan memutuskan untuk mengambil pembiayaan mudharabah di KJKS BMT Bina Ummat Sejahtera Cabang Utama Lasem sebaiknya tidak perlu mencemaskan nisbah bagi hasil, karena nisbah bagi hasil diperhitungkan sesuai dengan laba yang diperoleh setiap periode.

b. UMKM yang akan memutuskan untuk mengambil pembiayaan mudharabah di KJKS BMT Bina Ummat Sejahtera Cabang Utama Lasem sebaiknya tetap memperhatikan besarnya laba yang diperoleh setiap periodenya, karena lembaga keuangan akan tertarik berinvestasi atau memberikan bantuan modal apabila usaha yang dijalankan menguntungkan.

c. UMKM yang akan memutuskan untuk mengambil kredit ataupun pembiayaan sebaiknya lebih cermat dalam memperhatikan besarnya tingkat suku bunga yang ditawarkan ataupun persentase bagi hasil yang ditawarkan oleh lembaga keuangan.

d. UMKM sebaiknya tidak perlu ragu-ragu untuk mengambil tambahan modal dengan mengambil pembiayaan mudharabah karena pembiayaan mudharabah akan membantu untuk 


\section{JURNAL NOMINAL / VOLUME V NOMOR 1 / TAHUN 2016}

menambah laba pada usaha yang dijalankan.

e. Penelitian yang selanjutnya sebaikknya meneliti variabel sistem bagi hasil, laba, dan tingkat suku bunga secara langsung tanpa menggunakan persepsi. Dengan demikian dapat diketahui nilai-nilai dari masing-masing variabel secara langsung dan memperkecil tingkat kesalahan penilaian.

f. Penelitian selanjutnya sebaikknya menggunakan subjek penelitian dengan ruang lingkup yang lebih luas. Sehingga hasil penelitian yang nantinya diperoleh dapat lebih menggambarkan keadaan yang sebenarnya.

\section{DAFTAR PUSTAKA}

Anifah. (2009). Pengaruh Profit Sharing dan Suku Bunga Terhadap Kinerja Bank Syariah Indonesia. Skripsi. UIN Maulana Malik Ibrahim Malang.

Azwar Saifuddin (2010). Sikap Manusia: Teori dan Pengukurannya. Yogyakarta: Pustaka Belajar.

Gendro Wiyono. (2011). Merancang Penelitian Bisnis dengan Alat Analisis SPSS 17.0 \& PLS 2.0. Yogyakarta: UPP STIM YKPN Yogyakarta.

Imam Ghozali. (2011). Aplikasi Analisis Multivariate dengan Program IBM SPSS 19. Semarang: Badan Penerbit Universitas Diponegoro.

Kementrian Koperasi dan Usaha Kecil dan Menengah Republik Indondesia.
(2012). Perkembangan Data Usaha Mikro, Kecil, Menengah (UMKM) dan Usaha Besar (UB) Tahun 20112012. Diambil dari : http://www.depkop.go.id/, pada 16 Maret 2014.

Rio Sudirman. (2006). Faktor-Faktor yang Mempengaruhi Perilaku Nasabah untuk Mengambil Kredit pada Koperasi Bhakti Husada di Dinas Kesehatan Kabupaten Banyuwangi. Jurnal Ilmiah Vol.3. No.7 April 2006.

Sugiyono. (2001). Metode Penelitian Bisnis. Bandung: Alfabeta. ., (2010). Statistik untuk Penelitian. Bandung: Alfabeta. ., (2012). Metode Penelitian Kuantitatif, Kualitatif, dan Kombinasi (Mixed Methods). Bandung: Alfabeta. 